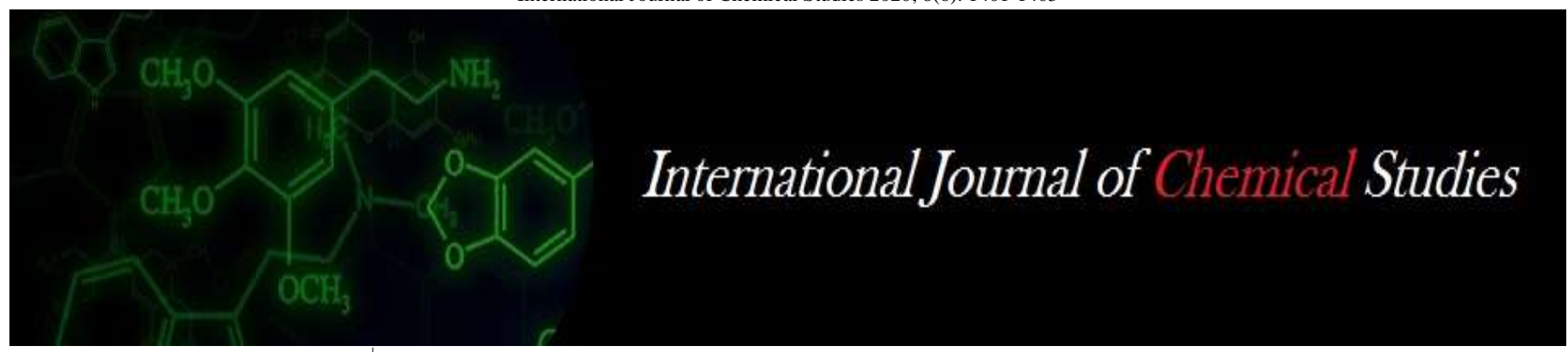

P-ISSN: 2349-8528

E-ISSN: 2321-4902

www.chemijournal.com

IJCS 2020; 8(6): 1401-1403

(C) 2020 IJCS

Received: 26-08-2020

Accepted: 23-10-2020

\section{Sahil Kumar}

Department of Agronomy,

School of Agriculture, Lovely

Professional University,

Jalandhar, Punjab, India

Dr. Gurpreet Singh

Lovely Professional University,

Jalandhar, Punjab, India

\section{Different weed flora in maize: A review}

\section{Sahil Kumar and Dr. Gurpreet Singh}

DOI: https://doi.org/10.22271/chemi.2020.v8.i6t.10958

\begin{abstract}
Weeds constitute one of the major financial significant issue for maize producers and they can diminish the yield up to 86 percent. The different weed flora found in different experimental fields of maize are Commelina benghalensis, Ageratum conyzoides, Echinochloa colona (L.), Panicum dichotomiflorum, Cyperus, Digitaria sanguinalis, Polygonum alatum, Commelina benghalensis, Dactyloctenium aegyptiacum, Ageratum conzoides, Acrachne racemosa, Eragrostis tenella, Digitaria sanguinalis, Trianthema portulacastrum, Phyllanthus niruri, Euphorbia hirta, Digera arvensis, Amaranthus viridis, Cyperus rotundus, Cyperus irria, Fimbristylis miliacea, Cleome viscosa, Phyllanthus niruri, Euphorbia hirta among dicots and Cynodon dactylon, Panicum repens and Dactyloctenium aegyptium, Commelina nudifolia, Ageratum conyzoides, Trianthema portulacastrum, Cleome gynandra, Datura stramonium, Digera arvensis, Corchorus olitorius, Physallis minima, Brachiaria spp., Asphodelus tenuifolius L. Cav., Polygonum alatum, Portulaca oleracea etc.
\end{abstract}

Keywords: Maize, weed flora, sedges weed shift etc.

\section{Introduction}

Maize (Zea mays L.) is also called as "Queen of Cereals". It is a cross pollinated crop and at harvest its grain contain about $4 \%$ of oil substance and $8-10 \%$ of protein. Maize is one among the principal significant oats inside the world rural economy both as a food and grub crop. It has better return potential than some other oat. It involves a territory of 9.23 mha with creation of $25.66 \mathrm{mt}$. and normal efficiency of $2.56 \mathrm{t} / \mathrm{ha}$ in the nation (Anonymous 2015). There are a few purposes behind lower creation of maize in our nation, among them high weed pervasion and their helpless administration and inappropriate planting techniques are basic issues. Maize crop is exceptionally invaded with weeds both in watered just as rainfed territories. They lessen the harvest yield from 20-40\% relying on weed species and thickness. Yield loss because of weed in maize shifts from 28 to $93 \%$, contingent upon the sort of weed greenery and power a length of harvest weed rivalry. In Kharif season, weeds are the difficult issue in maize as they view for light, supplement, and water and causes yield misfortunes(loss) up to 30-half. Maize grains are used for human utilization, as a feed for poultry and domesticated animals, for extraction of edible oil and furthermore for starch and glucose industry. It is called as a "wonder crop" with extremely high return potential. In India, maize is developed over a zone of 8.33 million ha with a yearly creation of about 16.68 million tons and a normal efficiency of around $2002 \mathrm{~kg} / \mathrm{ha}$. Maize possesses a zone of 1.07 million ha with a yearly creation of about 3.03 million tons as a normal efficiency of $2833 \mathrm{~kg} / \mathrm{ha}$. Weeds develop quickly and competing with the yield severely for development assets viz., supplements, dampness, day light and space during whole vegetative development and early conceptive phases of maize. They like wise happen to be part of significant distribute reduce and retain enormous amounts of supplements from the soil. Further, wide space given to the maize, permits quick development of assortment of weed species causing an impressive decrease in yield by influencing the development and yield ascribing segments. The presence of weeds decreases the photosynthetic proficiency, dry issue creation and dispersion to practical parts and there by diminishes sink limit of harvest bringing about helpless grain yield. Along these lines, the level of reduction in grain yield of maize has been represented to be in the extent of 33 to 50 percent relying upon kind of weed species in standing harvest. It is entrenched that 30 to 60 DAS is the most basic time frame for crop-weed rivalry in maize. Weed pervasion being the significant imperative in maize creation is extreme in the blustery season because of its more extensive dispersing.
Corresponding Author: Sahil Kumar

Department of Agronomy, School of Agriculture, Lovely Professional University, Jalandhar, Punjab, India 
Ranchers embrace diverse area explicit practices to reduce this biotic worry for improving efficiency. Nonetheless, the after effects of this examination showed low to high scope of genuine yield loss $(8.6-51 \%)$ because of weeds. Wide scope of yield misfortunes demonstrated the high variety among the information revealed by various areas. Beforehand, Mani et al., (1968) ${ }^{[8]}$ revealed 29-70\% yield misfortune because of weeds. Weed invasion is one of the significant reasons for low efficiency of maize. The normal yield misfortune because of weed in maize in India is $29.5-74.0 \%$. The uncontrolled weeds at basic time of harvest, weed rivalry decreased the development and improvement and in this manner yield of maize by $30-95 \%$ relying on type and force of weed invasion.

\section{Different types of weed flora in maize}

Chopra and Angiras, (2007) [6] recorded that in the experimental field were Panicum dichotomiflorum (13.84\%), Digitaria sanguinalis (38.08\%), Commelina benghalensis (11.54\%), Echinochloa colona (25.37\%), Cyperus iria $(4.96 \%)$ Oxalis latifolia, Brachiaria ramosa (3.56\%) and others (5.70\%) including Ageratum conyzoides, Cynodon dactylon, and Polygonum alatum, Ipomoea purpurea found in maize field. Walia et al., (2007) ${ }^{[19]}$ reported that experimental field had enough weed population especially of Acrachne racemosa (Gha) and Commelina benghalensis (Kaon Makki), apart from these, few other weeds i.e., Trianthema portulacastrum (It-sit), Digera arvensis (Tandla), Amaranthis viridis (Chulai), Eleusine spp. (Madhana) and Eragrostris spp. (Chirian da dana) in maize. Tahir et al., (2009) [17] reported that in experimental field Cyperus rotundus (Deela), Tribulus terrestris (Bakhra), Dactyloctenium aegyptium (Madhana grass), Cynodon dactylon (Khabal grass), Fumaria indica (Shahtara), Chenopodium album (Bathu), Convolvulus arvensis (lehli), Rumex dentatus (Jangli Palak) and Portulaca oleracea (Kulfa) in maize crop. Kumar et al., (2012) [2] observed that weed flora experimental field Ageratum conyzoides (45.1 and 56.1\%), Commelina benghalensis (25.6 and $12.3 \%$ at 60 ), Panicum dichotomiflorum (8.4 and $7.7 \%$ ), Echinochloa colona (L.) (17.6\% and $8.7 \%)$, Digitaria sanguinalis (0.0 and 8.2\%), Cyperus iria (2.8 and7.2\%) and Polygonum alatum (0.5 and $8.0 \%$ ) also showed its sporadic occurrence especially in the treated plots in maize. Arvadiya et al., (2012) ${ }^{[13]}$ recorded that weed flora in the experimental field Commelina benghalensis, Dactyloctenium aegyptiacum, Ageratum conzoides, Acrachne racemosa, Eragrostis tenella, Digitaria sanguinalis, Trianthema portulacastrum, Phyllanthus niruri, Euphorbia hirta, Digera arvensis, Amaranthus viridis, Cyperus rotundus, Cyperus irria and Fimbristylis miliacea in maize.Kannan and Chinna gounder, (2014) ${ }^{[9]}$ reported that dominant among broad leaved weeds were Trianthema portulacastrum, Cleome gynandra, Datura stramonium, Digera arvensis, Corchorus olitorius and Physallis minima in maize crop field. RK et al., (2014) ${ }^{[14]}$ observed that monocot weeds viz., Indigofera glandulosa L. (8.8\%), Brachiaria spp. (19.0\%), Panicum coloratum L. (2.4\%), Asphodelus tenuifolius Cav. (9.5\%), and Dactyloctenium aegyptium (L.) Willd (1.3\%) and dicot weeds viz., Amaranthus viridis L. (6.0\%), Digera arvensis Forsk (21.0\%), Acanthospermum hispidum DC. (3.7\%), Euphorbia hirta L. (2.0\%), Launaea nudicaulis L. (2.3\%), Portulaca oleracea L. (1.4\%), Chenopodium album L. (1.6\%), and Celosia argentea L. (1.0\%) and sedge weed Cyperus rotundus L. $(20.0 \%)$ in maize (sweet corn) field. Samant et al., (2015) [15] identified the major weeds in maize field Cynodon dactylon, Echinochloa colona, Commelina communis, Alternenthara sessilis, Digera arvensis, Parthenium hysterophorus, Argemone Mexicana, Cyperus rotundus during both the years found in maize field. Barad et al.,
(2016) ${ }^{[3]}$ observed that weed flora in maize experimental field Indigofera glandulosa L. (1.40\%), Brachiaria spp. (17.67\%), Echinochloa colona L. (1.23\%), Asphodelus tenuifolius L. Cav. (1.79\%), and Dactyloctenium aegyptium Beauv (4.79\%), dicot weeds viz., Digera arvensis Forsk (19.21\%), Physalis minima L. (2.77\%), Amaranthus viridis L. (2.28\%), Launaea nudicaulis L. (1.79\%), Chenopodium album L. (19.70\%), Euphorbia hirta L. (7.77\%), Phyllanthus niruri (2.02\%),Portulaca oleracea L. (3.52\%) and sedge weed Cyperus rotundus L. (21.29\%) in Rabi maize (pop-corn). Kaur et al., (2016) ${ }^{[10]}$ recorded that experimental field had enough population of Acrachne racemosa, Dactyloctenium aegyptiacum, Commelina benghalensis, Eragrostis tenella, Digitaria sanguinalis, Echinochloa colona, Trianthema portulacastrum, Phyllanthus niruri, Euphorbia hirta, Euphorbia microphylla, Digera arvensis, Amaranthus viridis, Cyperus rotundus, Cyperus compressus in maize. Barla et al., (2016) ${ }^{[4]}$ that reported experimental field was infested with broad leaved weeds like Alternenthara sessilis, Commelina benghalensis, Commelina nudifolia, Ageratum conyzoides, Phyllanthus niruri; among grassy weeds Echinochloa colona, Echinochloa crusgalli, Digitaria sanguinalis, Paspalam distichum, Dactyloctenium aegyptium and among sedges Cyperus rotundus, Cyperus irria and Fimbristylis milliaceae found in maize. Hargilas, (2016) ${ }^{[7]}$ observed uniform infestation of the grassy weeds Echinochloa crusgalli, Dactyloctenium aegypticum Eleusine indica, Panicum repense, Eragrostis sp. Digitaria ramose, Dinebra retroxa, Cynodon dactylon, Cyperus rotundus, Sorghum halepense were dominant grassy species while Trianthema portulacastrum, Commelina benghalensis, Amaranthus viridis, Cleome viscosa, Alternenthera echinata, Euphorbia genicullata, Euphorbia hirta, Phylanthus niruri, Digera arvensis, Abutilon indicum, Eclipta alba, Acalypha indica, Parthenium hysterophorus, Xanthium strumarium, Tribulus terrestris, Acaranthus aspera were dominated broad leaved weeds in maize. Rao et al., (2016) ${ }^{[5]}$ observed that weed flora was composed of Cleome viscose among sedges, Trianthema portulacastrum, Cyperus rotundus, Phyllanthus niruri and Euphorbia hirta dicots and Panicum repens, Cynodon dactylon, and Dactyloctenium aegyptium weed species in maize.

Jadhav, (2017) ${ }^{[1]}$ reported that broad leaved weeds Euphorbia genicullata, Acalypha indica, Parthenium hysterophorus, Digera arvensis, Mereimia emerginata, Ipomea maxima,Alternanthera sessilis, were found to be dominant species, grassy weeds were Cynodon dactylon, Brachiaria eruciformis, Cyperus rotundus and Amischophacelus cuculata were dominant found in maize. Singh et al., (2017) observed in the experimental field were Commelina benghalensis, Dactyloctenium aegyptiacum, Ageratum conizoides, Acrachne racemosa, Eragrostis tenella, Digitaria sanguinalis, Trianthema portulacastrum, Phyllanthus niruri, Euphorbia hirta, Digera arvensis, Amaranthus viridis, Cyperus rotundus, Cyperus irria and Fimbristylis miliacea found in maize field. Kumar et al., (2017) ${ }^{[2]}$ observed that dominant weeds are present in maize experimental field Cyperus rotundus L., Cynodon dactylon L., Argemone mexicana L., Amaranthus viridis L., Anagalis arvensis $L .$, Melilotus indica $L$. , Chenopodium album L., Convolvulus arvensis L., Oxalis corniculata L., Parthenium hysterophorus L. and Rumex retroflex $L$. in maize. Tomar et al., (2017) ${ }^{[18]}$ recorded that seven major weeds species three grassy weeds, Dactyloctenium aegyptium (L.) Achrachne racemosa and Setaria glauca (L.) one sedges (Cyperus rotundus L.) and three broad leaved weeds [Trianthema portulacastrum L., Digera arvensis (L), Commelina benghalensis L.] found in maize field.Akhtar et al., (2017) observed that broad leaved weeds Phyllanthus niruri (5.88-6.92\%) and Solanum nigrum 
(3.76-4.24\%), while the grassy weeds includes Cynodon dactylon (8.67-17.92\%), Digitaria sanguinalis (5.32-6.13\%) and Sorghum halpense (3.62-4.24\%), Cyperus rotundus (57.41-66.41\%) found in maize. Yadav et al., (2018) [20] reported that different weed species Dactyloctenium aegyptium, Brachiaria reptans, Digitaria sanguinalis, Leptochloa chinensis, Echinochloa colona among grasses and Euphorbia hirta and Amaranthus viridis among broad-leaf weeds, and Cyperus rotundus found in maize field. Satheesh et al., (2018) ${ }^{[8]}$ observed that important weed floras in the experimental field were Cyperus rotundus, Trianthema portulacastrum, Cynodon dactylon, Echinochloa crusgalli, Commelina benghalensis, Phyllanthus niruri and Cleome viscosa. Among the weed species, recorded four weed species namely Cyperus rotundus, Trianthema portulacastrum, Cynodon dactylon and Echinochloa crusgalli were occurring in the major proportion in maize.

\section{Conclusion}

The size of misfortunes generally relies on the piece of weed venture, time of harvest, weed rivalry and their capacity to compete for the essential components with crop plants. Different weeds that are present commonly in maize crop are Amaranthus viridis L., Cynodon dactylon L., Anagalis arvensis L., Cyperus rotundus L., Argemone mexicana L., Melilotus indica L., Chenopodium album L., Oxalis corniculata L., Rumex retroflex L., Convolvulus arvensis L. and Parthenium hysterophorus L, Echinochloa crusgalli, Dactyloctenium aegypticum Eleusine indica, Panicum repense, Eragrostis sp. Digitaria ramose, Dinebra retroxa, Commelina benghalensis, Trianthema portulacastrum, Physallis minima, Datura stramonium, Digera arvensis, Cleome gynandra, and Corchorus olitorius.

\section{References}

1. Jadhav AS. Effect of Different Weed Management Practices on Weed Dry Matter and yield of maize (Zea mays L.). International Journal of Science, Environment and Technology 2017;6(1):765-769.

2. Akhtar P, Kumar A, Kumar J, Sharma N, Stanzen L, Sharma A. Bio-efficacy of Post Emergent Application of Tembotrione on Mixed Weed Flora in Spring Maize (Zea mays L.) Under Irrigated Sub-tropical Shiwalik Foothills of J\&K, India. International Journal of Current Microbiology and Applied Sciences 2017;6(12):16191626.

3. Barad B, Mathukia RK, Gohil BS, Chhodavadia SK. Integrated weed management in rabi popcorn (Zea mays var. everta). Journal of Crop and Weed 2016;12(1):150153.

4. Barla S, Upasani RR, Puran AN, Thakur R. Weed management in maize. Indian Journal of Weed Science 2016;48(1):67-69.

5. Ch Rama Rao, Prasad PVN, Venkateswarlu B. Assessment of Different herbicides on yield and economics of kharif maize (Zea mays L.). International Journal of Agricultural Science and Research (IJASR) 2016;6(6):409-414.

6. Chopra PANKAJ, Angiras NN. Influence of tillage and weed control methods on growth, productivity and quality of maize (Zea mays L.). Journal of Crop and Weed 2007;3(2):10-14.

7. Hargilas. Integrated Weed Management in Maize (Zea mays L.) for Sustainable Productivity and Profitability of Maize-Wheat Cropping System in Southern Rajasthan. International Journal of Bio-resource and Stress Management 2016;7(3):382-387.

8. Satheesh J, Ramesh S, Manimaran S, Sudhakar P. Effect of new generation herbicides on weed dynamics and weed control efficiency in maize. Journal of Emerging Technologies and Innovative Research 2018;5(4):859866.

9. Kannan S, Chinnagounder C. Effect of glyphosate on weed management and grain yield in Kharif maize of transgenic stacked and conventional maize hybrids for higher productivity. African Journal of Agricultural Research 2014;9(2):269-275.

10. Kaur T, Kaur S, Bhullar MS. Management of complex weed flora in maize with post-emergence herbicides. Indian Journal of Weed Science 2016;48(4):390-393.

11. Kumar B, Prasad S, Mandal D, Kumar R. Influence of integrated weed management practices on weed dynamics, productivity and nutrient uptake of rabi maize (Zea mays L.). International Journal of Current Microbiology and Applied Sciences 2017;6(4):14311440.

12. Kumar S, Rana SS, Chander N, Angiras NN. Management of hardy weeds in maize under mid-hill conditions of Himachal Pradesh. Indian Journal of Weed Science 2012;44(1):11-17.

13. Arvadiya LK, Raj VC, Patel TU, Arvadia MK, Patel AM. Effect of plant population and weed management practices on productivity of sweet corn. Indian Journal of Weed Science 2012;44(3):167-171.

14. Mathukia RK, Dobariya VK, Gohil BS, Chhodavadia SK. Integrated Weed Management in Rabi Sweet Corn (Zea mays L. var. Saccharata). Advances in Crop Science and Technology 2014,1-3.

15. Samant TK, Dhir BC, Mohanty B. Weed growth, yield components, productivity, economics and nutrient uptake of maize (Zea mays L.) as influenced by various herbicide applications under rainfed condition. Scholars Journal of Agriculture and Veterinary Sciences 2015;2(1B):79-83.

16. Singh K, Kumar S, Singh L, Partap R. Effect of integrated weed management on weeds, growth and yield attributes of maize (Zea mays L.) In central plain zone of punjab. Agriways 5(2),79-85.

17. Tahir M, Javed MR, Tanveer A, Nadeem MA, Wasaya A, Bukhari SAH. Effect of different herbicides on weeds, growth and yield of spring planted maize (Zea mays L.). Pakistan Journal of Life and Social Sciences 2009;7(2):168-174.

18. Tomar SS, Singh R, Singh A, Singh A, Yaday A, Sharma J. Effect of different herbicides combination on weed flora, yield and economics of maize (Zea mays L.).Journal of Pharmacognosy and Phytochemistry SP1,465-469.

19. Walia US, Singh S, Singh B. Integrated control of hardy weeds in maize (Zea mays L.). Indian Journal of Weed Science 2007;39(1-2):17-20.

20. Yadav DB, Yadav A, Punia SS, Duhan A. Tembotrione for post-emergence control of complex weed flora in maize. Indian Journal of Weed Science 2018;50(2):133136. 